\title{
Development of transport infrastructure in modern megalopolises
}

\author{
Angela Mottaeva ${ }^{1 *}$ and Elena Vasilyeva ${ }^{1}$ \\ ${ }^{1}$ Moscow State University of Civil Engineering, 129337, 26, Yaroslavskoye Shosse, Moscow, Russia
}

\begin{abstract}
The features of transport infrastructure of megalopolises are systematized in the article. The concept of the infrastructure development index is defined, its components are considered. The level of the transport infrastructure development in the largest megalopolises of Russia-Moscow and St. Petersburg is analysed, their place among the megalopolises of the world, according to the standard criteria, is presented. The research is based on statistical and analytical data from 2010 till 2018. The main directions of strategic development of transport infrastructure in the Russian megalopolises and expected indicators till 2030 are also considered. The authors point out the problems of road-and-transport infrastructure in megalopolises, but on the other hand they reveal the advantages of megalopolises, which contribute to the development of their transport complexes.
\end{abstract}

\section{Introduction}

The most important factor of any megalopolis development is its transport complex and transport infrastructure in general. The transport complex represents the integration of the interconnected means of transport, capable to satisfy requirements of economy and population in passenger and cargo-transportations. Transport infrastructure is a broader category; it represents the set of all the branches and enterprises of transport both serving for passengers and freights $[1,2]$.

Transport infrastructure influences economic indicators of megalopolises, regions and the whole country significantly. The poor quality of transport infrastructure, weak coherence of the economic centres, their remoteness from large transport arteries becomes the factor, constraining the investment activity in the city (regions, country) and their development [3, 4].

The serious threat to the development of the modern megalopolis is the low ratio of housing and infrastructure [5]. Indeed, any megalopolis faces such a city-planning task as providing the maximum number of inhabitants with the pedestrian availability to transport hubs [6]. The research of the problems of the transport infrastructure and transport systems formation and development found reflection in the works by A.P. Abramov, V.M. Buneev, G.V. Veselov, V.G. Galaburda, V.V. Gasilov, A.E. Gorev, E.A. Gorin's, Yu.V. Zadvorny, P.V. Kurenkov, V.I. Mineev, L.B. Mirotin, N.V. Penshin, N.F. Permichev, V.A. Persianov,

\footnotetext{
*Corresponding author: angela-1309.m@yandex.ru
} 
L.N. Rudneva, I.A. Toymentseva, M.F. Trikhunkova, etc. Matters of the spatial organization of economic systems, taking into account the factors of infrastructure, are presented in the works by such scientists as P. Rosenstein-Rodan, A. Marshall, D. Clark, R. Frey, E. Simonis, Sh. Shtoner, D. Ray, R. Iokhimsen, R. Ford, K. Konkard, H. Seytts, H. Trebing, M. Dzhastmen, P. Samuelson, E.B. Alayev, Yu.O. Baklanov, S.A. Debabov, G.L. Zhuravleva, A.I. Kuznetsova, I.M. Mayergoyz, B.G. Preobrazhensky, I.E. Risin, I.A. Syomina, A.Yu. Sharipov, R.I. Shniper, E.G. Yasin. The works by I.A. Aksenov, E.L. Anoshkina, V.D. Badenko, V.N. Bugromenko, L.I. Vasilevsky, A.I. Gavrilov, A.L. Gaponenko, T.N. Gogoleva, A.G. Granberg, E.N. Zhiltsov's, M.G. Lapayeva, T.V. Mirolyubova, E.V. Mishon, A.M. Ozina, L.P. Pidoymo, V.G. Prudsky, L.I. Sverdlin, N.V. Sirotkina, Yu.I. Treshchevsky, O.F. Udalov, S.S. Ushakov, T.S. Khachaturov, U.G. Hansen, A. Harrell, A. Markusen, P. Niykamp, M.E. Porter, K. Shurmann, K. Shpikermann, D.G. Uordrop, M. Wegener, A.G. Wilson, etc. are devoted to studying of the problems of management in megalopolises, including management of the transport systems. However some theoretical and applied matters of the transport infrastructure development in megalopolises are not quite solved. The purpose of this article is to analyse the level of the development of the transport infrastructure of the largest megalopolises in Russia and in the world; to reveal the problems, interfering such development, and to define the most perspective directions of the development of transport in megalopolises.

\section{Terms and Methods}

The authors started their research with studying the results of the poll, conducted by AllRussian Public Opinion Research Centre (ARPORC) [1]. According to ARPORC, the problem of the road-and-transport infrastructure is one of the most important for all the regions the Russian Federation as whole and for every Russian megalopolis. Answering the question "Which of the aforesaid problems do you consider the most important for your region?" the significant share of the respondents named the transport problem as the most relevant one. At the same time the regularity, depending on the type of transport which respondents mainly use, is traced (Table 1 ).

Table 1. Assessment of the problem of the road-and-transport infrastructure by the users of different types of transport

\begin{tabular}{|c|c|}
\hline Types of transport, the respondents mainly use & $\begin{array}{c}\text { Share of the respondents, who } \\
\text { noted the transport problem } \\
\text { as the most relevant one, \% }\end{array}$ \\
\hline motor transport & 38 \\
\hline marine transport & 34 \\
\hline air traffic & 21 \\
\hline city passenger transport & 17 \\
\hline river transport & 16 \\
\hline railway transport & 14 \\
\hline bus traffic & 14 \\
\hline
\end{tabular}

This problem is the most relevant for the users of motor transport and marine transport. Those, who use public city transport, noted the problem of road-and-transport infrastructure as the main one much less often.

The basic and rather exact indicator, which was studied by the authors, is the index of the development of transport infrastructure [7,8].

The index was developed by Lomonosov Moscow State University for the assessment of the level of the development of transport infrastructure of megalopolises. It considers 5 components: 
1. Quality of transport service for the population.

It is characterized by the average time of a trip on different types of transport. This component includes the comfort of different types of transport, the existence of innovative services on transport, such as Wi-Fi; mobile programs for certain means of transport (for example "Moscow Metro"); electronic boards; help racks; payment by cash cards, virtual transport cards, mobiles; the order of container transportations by the means of iSales platform, etc., as well as convenience and reliability of the used systems and instruments of payment, etc. [9].

2. Availability of transport services for the population.

It is defined by existence of various transports (both traditional types, and innovations. such as car-sharing, hiring of electric vehicles or bicycle rental, etc.) The indicator includes volume and condition of the park of vehicles of different types, volume of passenger traffic, development of routes of different types (night, seasonal, social, to the airports, to large shopping centres, to places traditional rest of the population, popular cultural, religious centres, etc. $[10,11]$.

3. Safety.

It is characterized by the quantity of road accidents as well as by the severity of their consequences, introduction and improvement of security systems on transport, etc. $[12,13]$

4. Impact of transport on the environment

It is provided by the control of pollutants emission level in the atmosphere, by the existence of ecological standards for different types of transport, as well as the existence and prevalence of the use of eco-friendly means of transport, such as electro-buses, electric vehicles, and by transition to fuel of higher environmental standards [14].

5. Efficiency of cargo logistics

It is characterized by the development of cargo transport, existence of the corresponding infrastructure, existence of restrictions for the movement of cargo transport or ways of detour, cargo dimensional control, etc. [15].

The key problem of the development of the transport infrastructure of the megalopolis is the compliance to the international standards.

\section{Results}

As for the development of transport infrastructure Moscow is the most successful of the Russian megalopolises. The transport connection, provided by all the types of land transport (trams, buses, trolleybuses, share taxis; subway) is developed rather well in the capital, according to the Russian measures. Besides, there are several railway stations, an international airport, passenger and cargo ports in the territory of the city.

Now Moscow takes the 3rd place among the leading megalopolises of the world according to the level of the transport complex development, having moved from the 8th place, taken in 2010. St. Petersburg also enters the top ten of the leaders and it is in the 7 th place. Here is the ranking of the megalopolis of the world according to the index of development of their transport complexes:

$$
\begin{aligned}
& 1^{\text {st }} \text { place - Tokyo; } \\
& 2^{\text {nd }} \mathrm{pl} \text { - - London; } \\
& 3^{\text {rd }} \mathrm{pl} \text { - Moscow; } \\
& 4^{\text {th }} \mathrm{pl} \text { - New York; } \\
& 5^{\text {th }} \mathrm{pl} \text { - - Singapore; } \\
& 6^{\text {th }} \mathrm{pl} \text { - Shanghai; } \\
& 7^{\text {th }} \mathrm{pl} \text { - Saint-Petersburg; } \\
& 8^{\text {th }} \text { pl. - Hong Kong; } \\
& 9^{\text {th }} \mathrm{pl} \text { - - Istanbul; }
\end{aligned}
$$


$10^{\text {th }} \mathrm{pl}$. - Mexico.

It is also important, that in 2010-2015 Moscow was distinguished by the advancing growth rate of the index of development of the transport complex in comparison with the other megalopolises of the world.

The authors analysed the components of the index of the transport complex development, having revealed the top ten of the leaders for each point. Further the results of the analysis are presented $[16,17]$.

The quality of the transport services for the population of the megalopolis.

According to this indicator Moscow is in the 5th place among the megalopolises of the world, having moved from the 7th place, which it took in 2010. The top ten of megalopolises of the world according to the quality of transport services of is the following:

$1^{\text {st }}$ place - Tokyo;

$2^{\text {nd }}$ pl. - New York;

$3^{\text {rd }} \mathrm{pl}$. - Singapore;

$4^{\text {th }}$ pl. - London;

$5^{\text {th }}$ pl. - Moscow;

$6^{\text {th }}$ pl. - Shanghai;

$7^{\text {th }}$ pl. - Hong Kong;

$8^{\text {th }}$ pl. - Saint-Petersburg;

$9^{\text {th }}$ pl. - Istanbul;

$10^{\text {th }} \mathrm{pl}$. - Mexico.

From 2010 in 2017 the extent of highways as well as the extent of lines of the subway increased in Moscow, the share of the delay of trains in relation to the general time of a trip was considerably reduced. However, according to time, spent in traffic jams ( $\%$ of the general time of a way), Moscow is in the list of the "anti-record-holders", it takes the 3rd place. The 4th place is taken by another Russian megalopolis, St. Petersburg (Fig. 1).

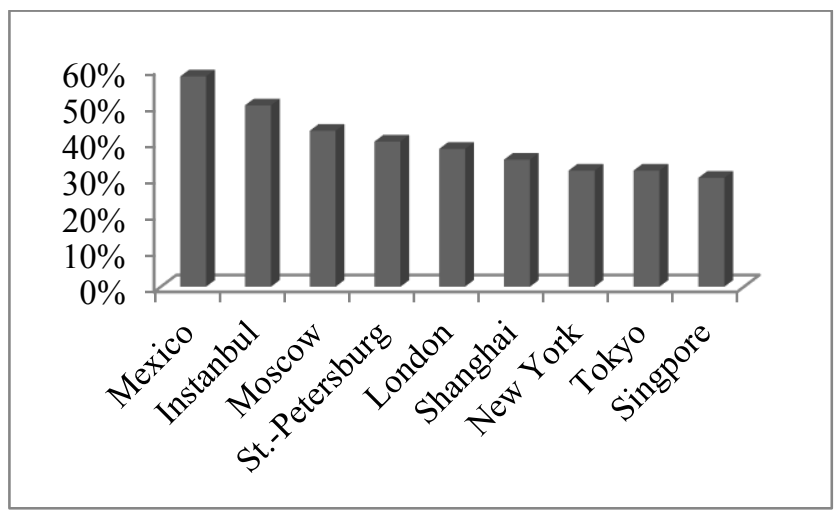

Fig 1. Approximate time, spent in traffic jams, in \% of time in way

There is a serious congestion of highways in the capital, and in the rush hours, during weather cataclysms or other adverse circumstances many kilometres traffic jams are formed. The solution of this problem can be promoted by the construction of new roads, platforms, outcomes, commissioning of the newly built Fourth Transport Circle, expansion of the available routes and the highway; construction of the extra street crosswalks providing the continuity of the movement [18]. In other words, the further growth of quality of transport services in the megalopolis requires the advancing increase in density of road networks.

Availability of transport services for the population. 
According to the index of the availability of transport services for the population megalopolises of the world can be ranged as follows:

$1^{\text {st }}$ place - New York;

$2^{\text {nd }}$ pl. - Tokyo;

$3^{\text {rd }} \mathrm{pl}$. - London;

$4^{\text {th }} \mathrm{pl}$. - Moscow;

$5^{\text {th }} \mathrm{pl}$. - Saint-Petersburg;

$6^{\text {th }}$ pl. - Singapore;

$7^{\text {th }}$ pl. - Istanbul;

$8^{\text {th }}$ pl. - Mexico;

$9^{\text {th }}$ pl. - Hong Kong;

$10^{\text {th }} \mathrm{pl}$. - Shanghai.

Among the Russian megalopolises Moscow and St. Petersburg have very high rates of the availability of transport services.

The number of users of land city passenger transport grows in Moscow steadily; noticeable increase in the passenger traffic of the subway takes place. The projects of multimodal transport hubs which would allow to optimize and coordinate the work of different types of transport are created and they are gradually implemented, to provide the population with comfortable and fast changes [19].

Besides, Moscow takes the 1st place according to the number of privately owned vehicles per 100 people of the population (growth was $25 \%$ to the level of 2010), and St. Petersburg takes the 3st place (Fig. 2).

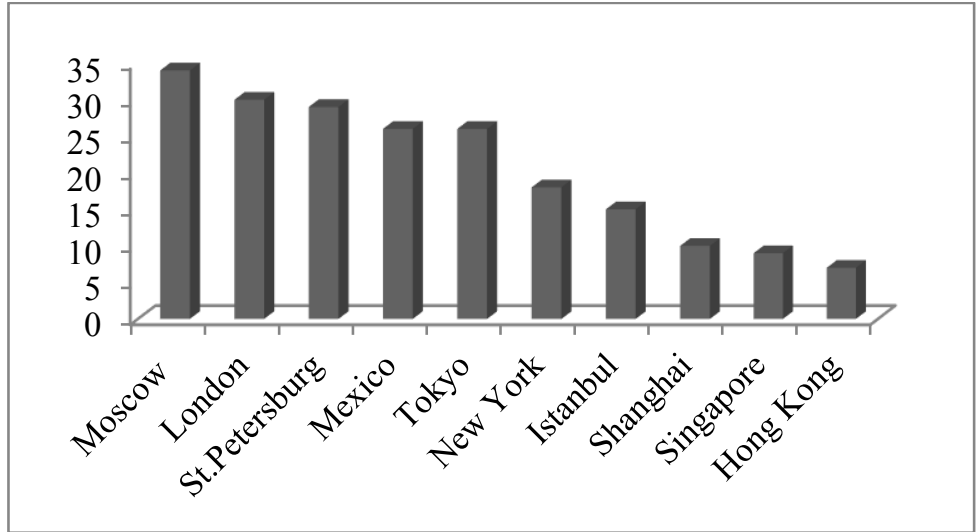

Fig. 2. The top ten of megalopolises of the world according to the number of privately owned vehicles (units per 100 people of the population)

Further increase in the availability of transport services is connected with the expansion of the park of vehicles (city transport of megalopolises), diversification of routes, growth of provision of the population with personal vehicles. However, the growth of the park of personal vehicles has serious restrictions, such as the income of the population (which growth rates in Russia lag behind the cost of the acquisition and the maintenance of the car) the lack of parking spaces (the common problem for megalopolises of the world).

Indicators of the traffic safety in the megalopolis and impacts on the environment.

In this aspect the introduction and active use of eco-friendly types of the city transport, better fuel, construction of the modern roads and outcomes, doing the movement more convenient and safer for all participants, introduction of new items, toughening traffic regulations for the benefit of safety, technical improvement of vehicles, decrease in indicators of accident rate and mortality in road accident is necessary [20,21]. 
It should be noted that tougher standards work long ago: so, since 2015 Euro-6, the environmental standard regulating the content of harmful substances in exhaust gases was entered. The previous Euro-5 standard worked for all new trucks, sold in the European Union since October, 2008, and it works for cars since September 1, 2009.

In Russia the ecological class Euro-5 was entered since January 1, 2016 according to Technical regulations \# 609 "On the requirements to emissions of harmful (polluting) substances by the automotive vehicles released in the territory of the Russian Federation". From now on, all the cars, in the territory of Russia (both domestic and imported; both new and second-hand; both for the personal purposes and for the commercial use) had to conform to this environmental standard. However the Government of the Russian Federation made the decision to prolong action of the Euro-4 standard and terms of the turnover of gasoline of Class 4. Actually the Euro-5 standard became obligatory since July 1, 2016. Further toughening of the environmental standards becomes complicated the low income of Russians, impossibility of their mass refusal of outdated budgetary models of cars (first of all - personal) [22]. But still positive dynamics takes place, Moscow moved from the 7th place to the 3rd place in the rating of safety and impact on the environment.

Top ten of megalopolises of the world according to the index of traffic safety and impact on the environment are the following:

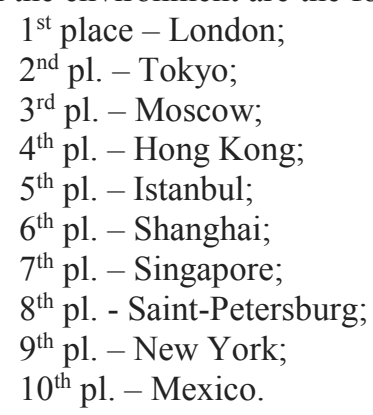

Rather pessimistic for Russia situation, is observed on the mortality rate in accidents (Fig. 3).

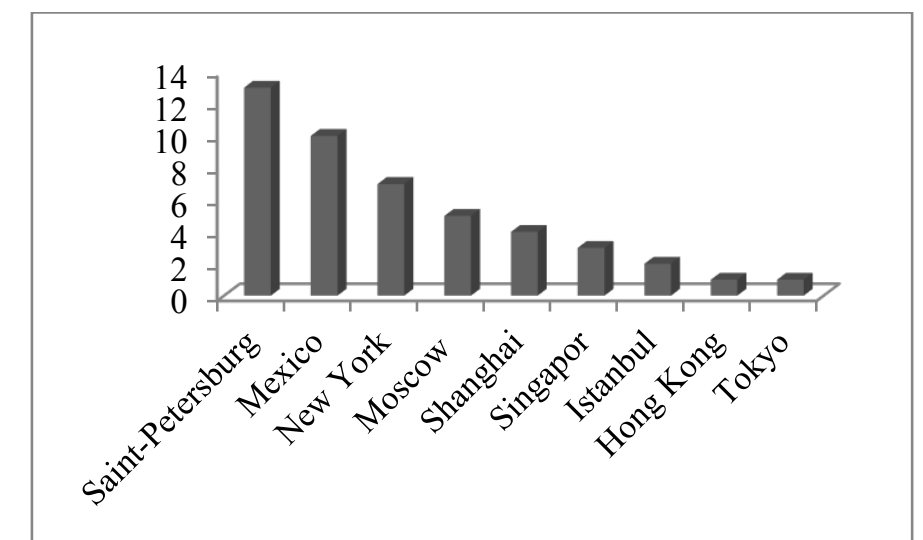

Fig. 3. Mortality in road accident in megalopolises of the world (cases per 100 thousand people)

\section{Efficiency of cargo logistics.}

In this aspect it is possible to note the growth of some specific indicators of provision with cargo transport, improvement of forwarding activity, the use of modern effective methods of the cargo transportation infrastructure, the creation and development of the logistic centres $[23,24,25]$. 
The Russian megalopolises Moscow and St. Petersburg have high indexes of this indicator, overtaking many business megalopolises. Here is the top ten of megalopolises of the world according to this criterion:

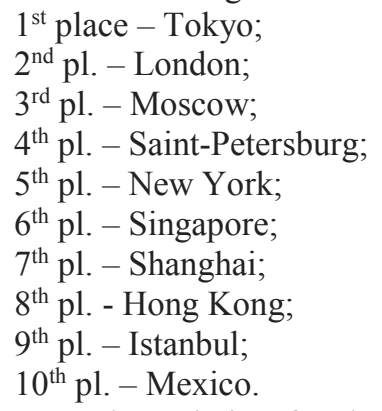

Natural restriction for the increase of the cargo park (first of all - automobile) is the density of the road network and also the lack of investments [26].

\section{Conclusion}

According to the results of the carried-out analysis we can conclude, that despite the insufficiently developed transport infrastructure of Russia in general, two of its largest cities - Moscow and St. Petersburg take rather high place in the rating of megalopolises of the world. This leadership is provided first of all with their capital functions, the status of the federal cities, rather good financing, the arrangement in the European part of the country. In general megalopolises have some advantages for the development of their transport infrastructure:

- stable demand for services of the city transport. So in Moscow only metro is used by 8.8 million of passengers daily.

- stable profitability of investments into the large city transport.

- possibility of commercialization of the city transport infrastructure.

- presence of qualified specialists.

- noticeable support of the city authorities.

In other cities it is necessary to apply the international experience to further development of the transport infrastructure, to intensify investments into the transport branch, including investments at the expense of the mechanism of public-and-private partnership (PPP).

- The main directions of the development can be mentioned:

- informatization of all the aspects of the transport process;

- integration of production and transport processes, development of transport logistics;

- the use of the ecology-focused and resource-saving transport technologies;

- strengthening of the state support.

\section{References}

1. All-Russian Public Opinion Research Centre (ARPORC), "Which of the aforesaid problems do you consider the most relevant for the region in which you live?" Results of the poll (Moscow, ARPORC, 2017)

2. INDEX of the development of the transport complex of megalopolises: Moscow urbanistic forum, on June 30 - on July 3 (Moscow, MSU, 2016)

3. Zhundrikov, A. Galaktionova, E. Yakunina, J. Dordzhiyeva, Infrastructure of Russia: index of development (Saint-Petersburg, INFRAOne Research, 2018) 
4. InfraONE Company, New Infrastructure markets and unimproved opportunities of old ones. What investment potential does private capital have and what restrictions does it face? Analitical Review (SPIEF, St. Petersburg, 2017)

5. Complex of Urban Policy and City Construction of Moscow News, legislative, methodical and analytical data, https://stroi.mos.ru/news/moskva-profinansiruietstroitiel-stvo-55-tpu?from=cl (2018)

6. H.T. Phuong, E. Scherbina, Basic research, 7, 373-378

7. H. Diell, Hebezeuge und Forderm 27 (2), 44-45 (1987)

8. V. Carbone, Maritime Policy \& Management 30 (4), 305-320 (2003)

9. N. Evreenova, World of Transport and Transportation 5, 170-176 (2014)

10. M. Panteleeva, S. Borozdina, MATEC Web Of Conferencies 106, 08047 (2017)

11. M. Panteleeva, S. Borozdina, MATEC Web Of Conferencies 106, 08048 (2017)

12. E. Vasilyeva, T. Sazonova, IOP Conference Series: Earth and Environmental Science, 90 (1), 012116 (2017)

13. Ž. Stevićet al., Sustainability, 10, 2817 (2018)

14. E. Vasilyeva, MATEC Web of Conferences, 193, 01025 (2018)

15. C. Woudsma et al., Transportation Research Procedia 12 474-488 (2016)

16. The United Nations Conference on Housing and Sustainable Urban Development, The New Urban Agenda (Austria, Vienna, 2017)

17. M. Vincent, Measurement Valuation of Public Transport Reliability (New Zealand, Wellington, 2008)

18. E. Sherbina, N. Danilina, D. Vlasov, International Journal of Applied Engineering Research 10 (22), 43131-43138 (2015)

19. Cities - transport, health and environment. Sixth Ministerial Conference on Environment and Health (Ostrava, Czech Republic, 2017)

20. V.R. Vuchic, Transportation for Livable Cities (CUPR/Transaction, 1999)

21. E. Vasilyeva, MATEC Web of Conferences, 170, 05005 (2018)

22. J. Jackisch, D. Sethi, F. Mitis, T. Szymanski, A. Arra, European facts and the global status report on road safety 2015 (Copenhagen, Denmark, WHO Regional Office for Europe, 2015)

23. S. Joss, R. Cowley, W. Martin de Jong, Y. Rydin, Tomorrow's City Today: Prospects for Standardising Sustainable Urban Development (London, University of Westminster, 2015)

24. O. Karpovich, A. Shlafman, IOP Conference Series Earth and Environmental Science 90(1), 012115, DOI: 10.1088/1755-1315/90/1/012115

25. M. Sternad, M. Knez, B. Rosi, Poslovna logistica u sovremenom menadžmentu, 9, 6976

26. E. Vasilyeva, I. Polyakova, MATEC Web of Conferences 106, 08097 (2017) 